\title{
Fibrous Ferrocement Composite with PVC-coated Weld Mesh and Bar-chip Polyolefin Fibers
}

\author{
P.B. Sakthivel ${ }^{1}$ and A. Jagannathan ${ }^{2}$ \\ ${ }^{1}$ Department of Civil Engineering, Jerusalem College of Engineering, Chennai, India; \\ ${ }^{2}$ Department of Civil Engineering, Pondicherry Engineering College, Puducherry, India
}

\begin{abstract}
This research is on Fiber Reinforced Ferrocement (FRF) composites using a new combination of two non-corrosive reinforcing materials, namely the PVC-coated steel weld mesh and synthetic barchip (polyolefin) fibers. A low-velocity impact study was conducted on $250 \mathrm{~mm}$ square fibrous ferrocement slab elements of $25 \mathrm{~mm}$ thick reinforced with PVC-coated weld mesh (III to V layers) and barchip olefin fibers (0.5\%$2.5 \%$ of volume of specimens). The energy absorbed by the FRF slabs was found to be higher than that of plain ferrocement slabs (cast with PVC mesh only). The impact energy increases with increase in the number of mesh layers, and also increases with increase in percentage of barchip fibers from $0.5 \%$ to $2.5 \%$. The initial and final crack-width reduce on increasing the proportion of polyolefin fibers in FRF slabs.
\end{abstract}

\section{Keywords: Cement Mortar, Crack Width, Energy Absorption, Polyolefin, Synthetic Fibers}

\section{INTRODUCTION}

Structural components, especially airport pavements and industrial floor overlays are subjected to severe impact loads [1] and very high stress rates occur due to dynamic loads as a large amount of energy is transmitted to the structure in a short duration of time [2]. For such applications involving high level of impact loads, Fiber Reinforced Ferrocement (FRF) elements (produced with weld mesh, hydraulic cement mortar and discontinuous fibers) that have an increased tensile strength, ductility, toughness, impact energy absorption capacity [2]-[4] and durability [5] are recommended by Sakthivel et al. (2011) [6] and Sakthivel and Jagannathan (2012 a) [7].

\subsection{Importance of Fibers}

Fibers, when added to cementitious matrix substantially increase the static and dynamic properties, changing an inherently brittle material with low tensile strength and impact resistance into a strong composite with superior crack resistance, improved ductility and distinctive post cracking behaviour to failure [8]. The strengthening mechanism of fibers involves transfer of stress from matrix to the fiber by interfacial shear or by interlock between the fibers and the matrix and improves the bonding characteristics [9]. Fibers bridging a crack can absorb energy by deforming and/or pulling out, depending on their bond characteristics [10]-[15]. Fibers resist the nucleation of cracks by acting as stress-transfer bridges, and once cracks nucleate, fibers abate their propagation by providing crack tip plasticity and increased fracture toughness [16]. The role of fibers as crack arrestors bridge the crack and its propogation [17], and controls the crack width of the member in cement-based composites [18]. As each type of fiber (metallic or synthetic fibers) is different in its composition and has varying properties, the impact tests allow the designers to compare the relative impact resistance of fiber reinforced cementitious composites under controlled laboratory conditions and come to a decision to select the fiber material or for quality control purposes [19], this study recommends impact study as the most important evaluation criteria in determining the strength of FRF composites.

\subsection{Research Gap}

Fibrous ferrocement is a new area of research and not many studies are available [7], [9] and hence an emphasis is needed on testing of FRF composites for impact and toughness [7]. Naaman (2000) [20]; ACI 549 [21] and Sakthivel and Jagannathan (2011) [22] have also recommended that new and innovative non-corrosive reinforcing materials may be employed in ferrocement composites and energy absorption capacity analysed under impact loads. Accordingly, Sakthivel and Jagannathan (2012 b) [23] have introduced a new non-corrosive mesh material in ferrocement, namely the PVC-coated steel weld mesh ('P' mesh) and conducted studies on flexural strength, and Sakthivel and Jagannathan (2012 c, d) [24], [25] on impact strength, and found that 'P' mesh is compatible with ferrocement. Subsequently, Sakthivel et al. (2012 a) [26] have experimented on cementitious matrix reinforced with discontinuous Stainless Steel (SS) fibers, and found out that there is an increase not only in its engineering properties such as compressive, split-tensile and mortar flexural strength but also in the energy absorption level of cementitious slabs when the percentage of SS fibers is increased from $0.5 \%$ to $2.5 \%$. Further, Sakthivel et al. (2012 b) [27] researched upon the influence of SS fibers $(0.5-2.5 \%)$ on ferrocement slab elements reinforced with several layers of ' $\mathrm{P}$ ' mesh, and the results show that there has been an increase in the energy absorption of FRF slabs.

\subsection{Objectives of this Study}

As a continuation of the above investigative works, the present study has made an attempt to find out the impact strength of FRF slab elements using a combination of PVCcoated weld mesh and a new type of synthetic fiber material, Bar-chip-54 Polyolefin fibers in proportions of $0.5 \%-2.5 \%$ of volume of specimens, and this paper has used terminologies 'P' mesh and "PL" fibers respectively.

\section{EXPERIMENTAL WORK}

For this experimental research, 45 nos. of FRF slabs (test specimens) of size $250 \mathrm{~mm}$ x $250 \mathrm{~mm}$ x $25 \mathrm{~mm}$ (thickness) were cast with multiple reinforcing combination of ' $\mathrm{P}$ ' mesh (III/ IV/ V layers) and 'PL' fibers (0.5-2.5\%) as follows: 


\section{Reinforcement Mix of Test Specimens (This Study)}

(a) P-III + PL-0.5\%; P-III + PL-1\%; P-III + PL-1.5\%; P-III + PL-2\%; and P-III + PL-2.5\% (representing III layer PVC-coated weld mesh and Barchip/ Polyolefin fibers)

(b) P-IV + PL-0.5\%; P-IV + PL-1\%; P-IV + PL-1.5\%; P-IV + PL-2\%; and P-IV + PL-2.5\% (representing IV layer PVC-coated weld mesh and Barchip/ Polyolefin fibers)

(c) P-V + PL-0.5\%; P-V + PL-1\%; P-V + PL-1.5\%; P-V + PL-2\%; and P-V + PL-2.5\% (representing V layer PVC-coated weld mesh and Barchip/ Polyolefin fibers)

\section{Control Specimens (from Previous Study):}

Sakthivel et al. (2012b) [27] have used ferrocement slabs reinforced with 'P' mesh (III/ IV/ V layers) as the control specimens, and this study has used the same results to compare the impact energy of FRF slabs of this study.

\subsection{Materials and Mix Proportions}

The plain and fibrous ferrocement mortar have been prepared using Ordinary Portland Cement (OPC) of 53 Grade, Penna Brand (conforming to IS 12269-1989 [28] as shown in Tables 1 and 2). The specific gravity of cement was found to be 3.14. Locally available river sand has been used as fine aggregate, and the sieve analysis (given in Table 3) conform to Zone II of IS 383:1970 [29]. The chemical properties of fine aggregates satisfies the IS 2386 (Part VII): 1963 [30] and are given in Table 4. The specific gravity of sand of 2.74 and water absorption of $1 \%$ satisfies the IS:383 1970 Code [29] (as given in Table 5), and other tests for sand (shown in Table 6) also satisfies the requirements of IS 383:1970 [29].

Table 1 Physical Properties of Cement (OPC 53 Grade)

\begin{tabular}{|c|c|c|c|c|}
\hline $\begin{array}{l}\text { S. } \\
\text { No. }\end{array}$ & $\begin{array}{l}\text { Test Conducted for } \\
\text { OPC } 53 \text { Grade }\end{array}$ & Results & $\begin{array}{l}\text { Requiremen } \\
\text { ts as per IS } \\
\text { 12269-1987 } \\
\text { (RA 2008) }\end{array}$ & Remarks \\
\hline 1. & Specific Gravity & 3.14 & -- & -- \\
\hline 2. & Consistency & $28.3 \%$ & $\begin{array}{l}\text { Not } \\
\text { Specified }\end{array}$ & \\
\hline 3. & Initial Setting Time & $\begin{array}{l}155 \\
\text { Minutes }\end{array}$ & $\begin{array}{l}\text { Shall not be } \\
\text { less than } 30 \\
\text { minutes }\end{array}$ & Passes \\
\hline 4. & Final Setting Time & $\begin{array}{l}355 \\
\text { Minutes }\end{array}$ & $\begin{array}{l}\text { Shall not be } \\
\text { more than } \\
600 \text { minutes }\end{array}$ & Passes \\
\hline \multirow[t]{4}{*}{5.} & $\begin{array}{l}\text { Compressive } \\
\text { Strength }\end{array}$ & & & \\
\hline & $\begin{array}{l}\text { a) } 72+\text { or }-1 \mathrm{~h} \\
\text { (average of three } \\
\text { results) }\end{array}$ & $\begin{array}{l}32.0 \\
\mathrm{MPa}\end{array}$ & $\begin{array}{l}\text { Shall not be } \\
\text { less than } 27.0 \\
\text { MPa }\end{array}$ & Passes \\
\hline & $\begin{array}{l}\text { b) } 168+\text { or }-2 \mathrm{~h} \\
\text { (average of three } \\
\text { results) }\end{array}$ & $\begin{array}{l}42.5 \\
\mathrm{MPa}\end{array}$ & $\begin{array}{l}\text { Shall not be } \\
\text { less than } 37.0 \\
\text { MPa }\end{array}$ & Passes \\
\hline & $\begin{array}{l}\text { c) } 672+\text { or }-4 \mathrm{~h} \\
\text { (average of three } \\
\text { results) }\end{array}$ & $\begin{array}{l}59.0 \\
\text { MPa }\end{array}$ & $\begin{array}{l}\text { Shall not be } \\
\text { less than } 53.0 \\
\text { MPa }\end{array}$ & Passes \\
\hline 6. & $\begin{array}{l}\text { Fineness by Blaine's } \\
\text { air permeability } \\
\text { method) }\end{array}$ & $\begin{array}{l}266 \\
\mathrm{~m}^{2} / \mathrm{kg}\end{array}$ & $\begin{array}{l}\text { Shall not be } \\
\text { less than } 225 \\
\mathrm{~m}^{2} / \mathrm{kg}\end{array}$ & Passes \\
\hline 7. & $\begin{array}{ll}\text { Soundness } & \text { (by } \\
\text { Le-Chatelier's } & \\
\text { method) } & \end{array}$ & $0.6 \mathrm{~mm}$ & $\begin{array}{l}\text { Shall not be } \\
\text { more than } 10 \\
\text { mm }\end{array}$ & Passes \\
\hline
\end{tabular}

Table 2 Chemical Properties of Cement (OPC-53)

\begin{tabular}{|c|c|c|c|}
\hline $\begin{array}{l}\text { S. } \\
\text { No. }\end{array}$ & $\begin{array}{l}\text { Test Conducted for } \text { Ordinary } \\
\text { Portland Cement (OPC-53 Grade) }\end{array}$ & $\begin{array}{l}\text { Results } \\
\text { (\%) }\end{array}$ & $\begin{array}{l}\text { Requireme } \\
\text { nt as per } \\
\text { IS: } \\
\text { 12269-1987 }\end{array}$ \\
\hline 1. & Total Loss on Ignition (\% by mass) & 2.22 & $\begin{array}{l}\text { Not more } \\
\text { than } 4 \%\end{array}$ \\
\hline 2. & Insoluble Residue (\% by mass) & 1.36 & $\begin{array}{l}\text { Not more } \\
\text { than } 3 \%\end{array}$ \\
\hline \multirow[t]{2}{*}{3.} & $\begin{array}{l}\text { Ratio of \% of Lime to \% of Silica, } \\
\text { Alumina and Iron Oxide, when } \\
\text { calculated by the formula: } \\
\mathrm{CaO}-0.7 \mathrm{SO}_{3}\end{array}$ & \multirow[b]{2}{*}{0.93} & \multirow[t]{2}{*}{$\begin{array}{l}\text { Not greater } \\
\text { than } 1.02 \\
\text { And not } \\
\text { less than } \\
0.80\end{array}$} \\
\hline & $2.8 \times \mathrm{Si} \mathrm{O}_{2}+1.2 \times \mathrm{Al}_{2} \mathrm{O}_{3}+0.65 \times \mathrm{Fe}_{2} \mathrm{O}_{3}$ & & \\
\hline 4. & Ratio of $\%$ of Alumina to Iron Oxide & 1.40 & $\begin{array}{l}\text { Not }<\text { than } \\
0.66\end{array}$ \\
\hline 5. & $\begin{array}{l}\text { Total Sulphur content calculated as } \\
\text { sulphuric anhydride }\left(\mathrm{SO}_{3}\right) \text { (\% by mass) }\end{array}$ & 2.39 & $\begin{array}{l}\text { Not }>\text { than } \\
2.5 \% \text { for } \\
\mathrm{C}_{3} \mathrm{~A}<\text { or } \\
=5 \% \\
\text { Not more } \\
\text { than } 3.0 \% \\
\text { for } \mathrm{C}_{3} \mathrm{~A}>5 \%\end{array}$ \\
\hline 6. & Magnesia (MgO), (\% by mass) & 1.04 & $\begin{array}{l}\text { Not more } \\
\text { than } 6 \%\end{array}$ \\
\hline 7. & $\begin{array}{l}\text { Tricalcium aluminate }\left(\mathrm{C}_{3} \mathrm{~A}\right) \text {, (\% by } \\
\text { mass) }\end{array}$ & 8.07 & -- \\
\hline
\end{tabular}

Table 3 Sieve Analysis of Fine Aggregate (Sand)

\begin{tabular}{|c|c|c|c|c|c|}
\hline \multirow[t]{2}{*}{$\begin{array}{l}\text { IS Sieve } \\
\text { Desig- } \\
\text { nation }\end{array}$} & \multicolumn{2}{|c|}{$\begin{array}{l}\text { Cumulative Percent } \\
\text { of Sand }\end{array}$} & \multicolumn{3}{|c|}{$\begin{array}{l}\text { Specification as per } \\
\text { IS:383-1970 (Reaffirmed } \\
\text { 2007) for Fine Aggregate } \\
\text { (Percentage Passing) } \\
\end{array}$} \\
\hline & Retained & Passing & $\begin{array}{l}\text { Zone } \\
\text { I }\end{array}$ & $\begin{array}{l}\text { Zone } \\
\text { II }\end{array}$ & $\begin{array}{l}\text { Zone } \\
\text { III }\end{array}$ \\
\hline $04.75 \mathrm{~mm}$ & 3.50 & 96.50 & $90-100$ & $90-100$ & $90-00$ \\
\hline $02.36 \mathrm{~mm}$ & 11.00 & 89.00 & $60-95$ & $75-100$ & $85-100$ \\
\hline $01.18 \mathrm{~mm}$ & 37.00 & 63.00 & $30-70$ & 55-90 & $75-100$ \\
\hline $\begin{array}{l}600 \\
\text { microns }\end{array}$ & 52.00 & 48.00 & $15-34$ & $35-59$ & $60-79$ \\
\hline $\begin{array}{l}300 \\
\text { microns }\end{array}$ & 90.00 & 10.00 & $5-20$ & $8-30$ & $12-40$ \\
\hline $\begin{array}{l}150 \\
\text { microns }\end{array}$ & 99.00 & 1.00 & $0-10$ & $0-10$ & $0-10$ \\
\hline
\end{tabular}

Table 4 Chemical Properties of Fine Aggregates

\begin{tabular}{|c|c|c|}
\hline $\begin{array}{l}\text { Test Conducted for } \\
\text { Sand }\end{array}$ & Results & Remarks \\
\hline $\begin{array}{l}\text { Alkali aggregate } \\
\text { reactivity: } \\
\text { (millimoles/ltr) }\end{array}$ & & $\begin{array}{l}\text { As per IS:2386 (Part } \\
\text { VII) } 1963 \text { the samples } \\
\text { fall under innocuous }\end{array}$ \\
\hline $\begin{array}{l}\text { a) Reduction in } \\
\text { Alkalinity of } \mathrm{NaOH}\end{array}$ & 40.00 & $\begin{array}{l}\text { aggregate, i.e., the } \\
\text { samples do not indicate }\end{array}$ \\
\hline b) Silica Dissolves & 17.82 & $\begin{array}{lrr}\text { potential } & \text { deleterious } \\
\text { degree of } & \text { Alkali } \\
\text { Reactivity } & & \end{array}$ \\
\hline
\end{tabular}

Table 5 Tests for Sand

\begin{tabular}{|l|l|c|}
\hline $\begin{array}{l}\text { Test Conducted for } \\
\text { Sand }\end{array}$ & Results & $\begin{array}{l}\text { Requirements as per } \\
\text { IS:383-1970 } \\
\text { 2007) }\end{array}$ \\
\hline Specific Gravity & 2.74 & -- \\
\hline $\begin{array}{l}\text { Water Absorption } \\
\text { (\%) }\end{array}$ & 1.00 & -- \\
\hline $\begin{array}{l}\text { Material finer than 75 } \\
\text { microns (\%) }\end{array}$ & 0.80 & Max. 3\% by weight \\
\hline
\end{tabular}


Table 6 Test Report on Fine Aggregate (Sand)

\begin{tabular}{|c|c|c|}
\hline $\begin{array}{l}\text { Test Conducted for } \\
\text { Sand }\end{array}$ & Results & $\begin{array}{l}\text { Requirements as } \\
\text { per IS:383-1970 } \\
\text { (Reaffirmed 2007) }\end{array}$ \\
\hline $\begin{array}{l}\text { Light weight pieces (\%) } \\
\end{array}$ & 0.30 & Max. $1 \%$ by weight \\
\hline Organic Impurities & $\begin{array}{l}\text { Intensity of the } \\
\text { colour developed by } \\
\text { the test specimen is } \\
\text { lighter than the } \\
\text { standard solution } \\
\text { indicating ro the } \\
\text { presence ref } \\
\text { insufficient quantity } \\
\text { of harmful organic } \\
\text { compounds }\end{array}$ & \begin{tabular}{lr}
\multicolumn{2}{l}{ The aggregate shall } \\
not contain harmful \\
organic impurities \\
in & sufficient \\
quantities & to effect \\
adversely & the \\
strength & or \\
durability & of \\
concrete &
\end{tabular} \\
\hline $\begin{array}{l}\text { Soundness (\%) (weight } \\
\text { loss after } 5 \text { cycles) }\end{array}$ & & \\
\hline $\begin{array}{l}\text { Sodium Sulphate } \\
\text { Magnesium Sulphate }\end{array}$ & $\begin{array}{l}3.88 \\
4.38\end{array}$ & $\begin{array}{l}\text { Max. } 10 \% \\
\text { Max } 15 \%\end{array}$ \\
\hline Chloride (\%), as $\mathrm{Cl}$ & 0.010 & --- \\
\hline Sulphate (\%), as $\mathrm{SO}_{3}$ & 0.048 & --- \\
\hline
\end{tabular}

This study has used PVC-coated weld mesh ('P' mesh, as shown in Fig. 1a, and its properties as in Table 7), manufactured by Della; and synthetic non-corrosive type of fibers, namely the Bar-chip Polyolefin (PL) fibers (as shown in Fig.1b) are manufactured by Elasto Plastic Concrete (EPC, Australia), and the properties of PL fibers are given in Table 8.

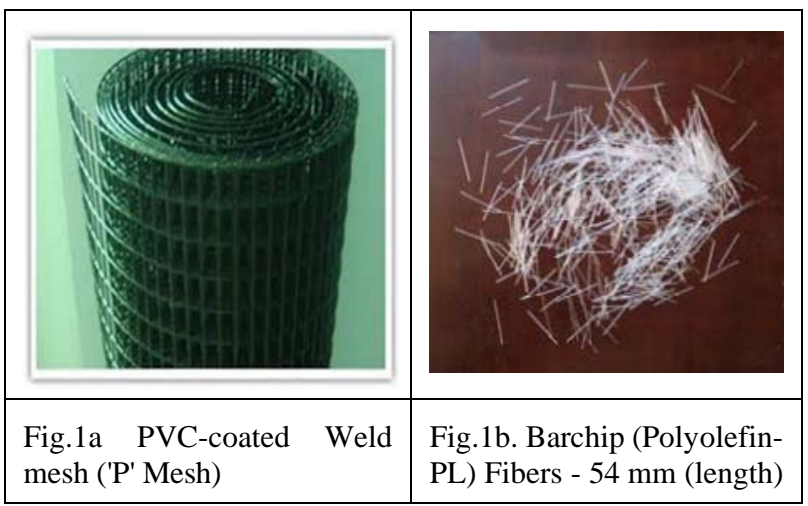

Table 7 Properties of PVC-coated Weld ('P') Mesh

\begin{tabular}{|c|c|}
\hline Tensile Strength $\left(\mathrm{N} / \mathrm{mm}^{2}\right)$ & 512.36 \\
\hline Yield Stress $\left(\mathrm{N} / \mathrm{mm}^{2}\right)$ & 406.51 \\
\hline Elongation (\%) & 7.12 \\
\hline Weld Shear $\left(\mathrm{N} / \mathrm{mm}^{2}\right)$ & 250 \\
\hline Outer Coating Material & PVC \\
\hline Density $\left(\mathrm{g} / \mathrm{cm}^{3}\right)$ & 7.82 \\
\hline Outer thickness (mm) & $0.83 \mathrm{~mm}$ (22 gauge) \\
\hline Inner Material thickness (mm) & $0.70 \mathrm{~mm}$ (24 gauge) \\
\hline $\begin{array}{l}\text { Outer Coating thickness } \\
\text { (PVC-coating) in microns }\end{array}$ & 7 to 9 \\
\hline $\begin{array}{l}\text { Inner Coating thickness } \\
\text { (Zinc-coating) in microns }\end{array}$ & 4 to 6 \\
\hline
\end{tabular}

Table 8 Properties of Bar-chip (Polyolefin - PL)Fibers

\begin{tabular}{|l|l|}
\hline Base Material & Modified Olefin \\
\hline Length of fiber $(\mathrm{mm})$ & 54 \\
\hline Tensile Strength $(\mathrm{MPa})$ & 640 \\
\hline Surface Texture & Continuously Embossed \\
\hline Specific Gravity & $0.90-0.92$ \\
\hline Young's Modulus $(\mathrm{GPa})$ & $10 \mathrm{GPa}$ \\
\hline Melting Point $\left({ }^{\circ} \mathrm{C}\right)$ & $150-170$ \\
\hline Ignition Point $\left({ }^{\circ} \mathrm{C}\right)$ & Greater than 450 \\
\hline
\end{tabular}

\subsection{Casting of Specimens}

The casting procedure of FRF slab (test) specimens for this study are in accordance with the research studies of Sakthivel et al. (2012 b) [27]. The sand was sieved, and the cement mortar with sand-cement ratio of 2:1 and watercement ratio of 0.43 was prepared in line with ACI-549 specifications [21]. Test Specimens were cast with fibrous ferrocement mortar using PL fibers ranging from $0.5 \%$ $2.5 \%$. The fibrous ferrocement mortar was prepared (Fig.2) by properly mixing the required amount of PL fibers to the cement mortar with measured quantity of water. Water used has been tested for its suitability towards construction purposes.

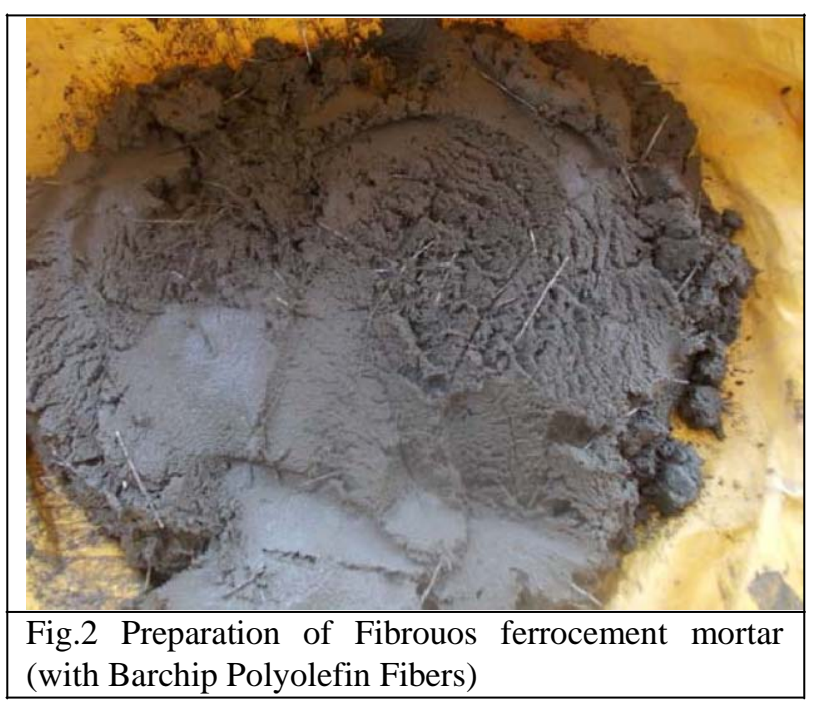

The casting of fibrous ferrocement slabs were done in wooden moulds as shown in Fig.3. The moulds were fabricated in such a way that it is easily detachable and the hardened slab removable without any damage to edges. Anyway, little amount of oil/grease is applied in the mould for easy demoulding of the specimens.

The $3 \mathrm{~mm}$ cover area was first laid with fibrous ferrocement mortar, and then the PVC-mesh was spread in position, and then the next layer of fibrous mortar was spread over the mesh top (as seen in Fig. 3), and the process has been repeated based on the number of meshes (III, IV or $\mathrm{V}$ layers) used.

Along with test specimens, reference specimens were also cast with plain cement mortar and fibrous ferrocement mortar (by adding PL fibers in cement mortar) to find out the engineering properties such as cube compressive strength, split tensile strength and mortar flexural strength. The reference specimens (3 nos.) were cast in standard moulds of cube size $100 \mathrm{~mm} \mathrm{X} 100 \mathrm{~mm} \mathrm{X} 100 \mathrm{~mm}$, cylinder size of $100 \mathrm{~mm}$ diameter and $200 \mathrm{~mm}$ height, and prism size of $40 \mathrm{~mm}$ X $40 \mathrm{~mm}$ X $160 \mathrm{~mm}$ respectively, and tested at 28 days, after required level of curing. 


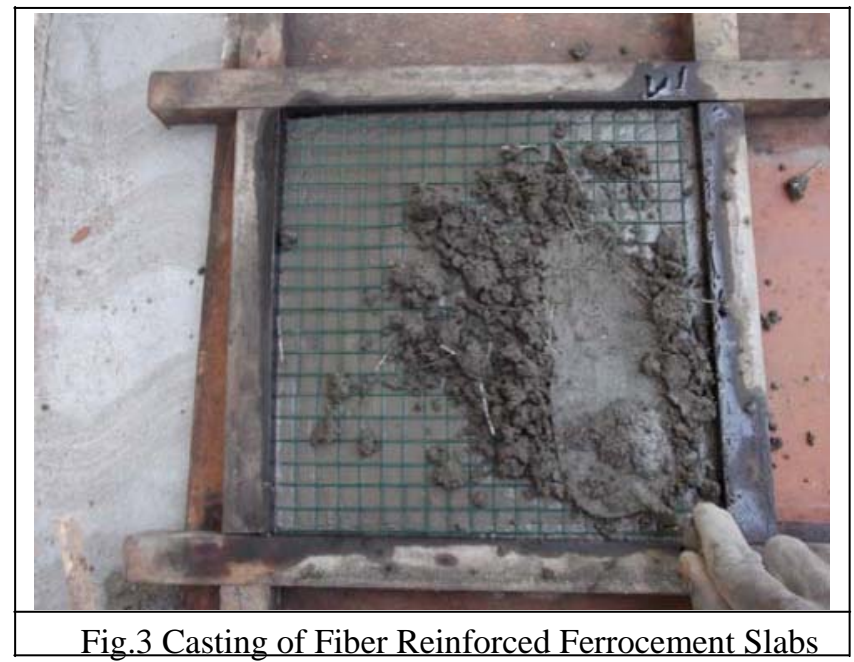

\subsection{Impact Test}

The impact test procedure is as per the studies of Sakthivel and Jagannathan (2012 c, d) [24] [25] and Sakthivel et al. 2012 [26]. The slab specimens were properly positioned on a steel frame on simply supported conditions. Low-velocity impact test has been conducted on these specimens by repeatedly dropping-off a $1 \mathrm{~kg}$ steel bob from a height of $600 \mathrm{~mm}$ through a simple free-fall technique. The number of blows received on appearance of initial and final cracks (at the bottom of the specimen) were noted down, and energy absorption is calculated in Joules and presented in Table 10. While conducting the impact study, vigorous monitoring of the experimental works has been done, and the initial and final crack formation were carefully studied. Even though the decision to stop the impact blows at ultimate failure has been mainly based on some change in the sound pattern, indicating that ultimate failure has taken place, the final decision has been taken by the present researchers based on their past experience in similar research works and judgment. In this study, the experiment has been conducted until the ultimate specimen failure only, and full failure/ damage of the specimen has not been attempted.

After the 28 day curing period, the slabs were dried and white-washed in order to visually and clearly identify the cracks, and each slab specimen is given an unique identification number. For example, PL 54 - III - 0.5\% (1) $B$ represents a set of characters: the first letter "PL" refers to the type of fibers (here, Polyolefin/ Barchip fibers), while the subsequent number 54 denotes the length of the fiber; the second and third set of characters III and $0.5 \%$ refers to the number of reinforcing mesh layers and percentage of fibers (to volume of specimens) respectively, and the subsequent number in bracket (1) denotes the specimen no.1, followed by alphabet B which indicates the "Bottom of Specimen."

\section{RESULTS AND DISCUSSIONS}

\subsection{Strength Properties of Cement Mortar}

The strength of hardened cement mortar at 28 days viz., compressive, split-tensile and mortar flexural strength were studied, which forms the criteria to evaluate the effect of adding Polyolefin fibers to cementitious composites [31]. The results of compressive strength, split tensile strength and mortar prism mortar flexural strength are given in Table 9.

Table 9 Strength of Reference Specimens of Plain and Fibrous Ferrocement Mortar (using Bar Chip Fibers)

\begin{tabular}{|r|r|r|r|}
\hline $\begin{array}{r}\text { \% of } \\
\text { Bar Chip } \\
\text { fibers } \\
\text { used in }\end{array}$ & $\begin{array}{r}\text { Compressive } \\
\text { Strength at } \\
\text { 28 days } \\
\text { Cement } \\
\text { Matrix }\end{array}$ & $\begin{array}{r}\text { Split-Tensile } \\
\text { Strength at } \\
\text { 28 days } \\
\text { (N/mm2) }\end{array}$ & $\begin{array}{r}\text { Mortar } \\
\text { Prism } \\
\text { Flexural } \\
\text { Strength } \\
\text { at 28 days } \\
\text { (N/mm2) }\end{array}$ \\
\hline 0.0 & & & \\
\hline 0.5 & 33.00 & 4.60 & 5.80 \\
\hline 1.0 & 33.50 & 4.87 & 6.08 \\
\hline 1.5 & 40.33 & 5.41 & 6.83 \\
\hline 2.0 & 45.00 & 5.64 & 7.88 \\
\hline 2.5 & 48.00 & 6.05 & 8.26 \\
\hline
\end{tabular}

From Table 9, it is evident that the compressive strength increases with the increase in volume of barchip fibers. The cube compressive strength for the plain ferrocement mortar at 28 days is found to be $33.00 \mathrm{~N} / \mathrm{mm}^{2}$, whereas for fibrous ferrocement mortar (i.e., cement mortar with barchip fibers) with $0.5 \%, 1.0 \%, 1.5 \%, 2.0 \%$ and $2.5 \%$, the cube compressive strength at 28 days is $33.50 \mathrm{~N} / \mathrm{mm}^{2}, 40.33$ $\mathrm{N} / \mathrm{mm}^{2}, 45 \mathrm{~N} / \mathrm{mm}^{2}, 48 \mathrm{~N} / \mathrm{mm}^{2}$ and $50 \mathrm{~N} / \mathrm{mm}^{2}$ respectively. The split tensile strength of cylinder specimens at 28 days has increased from $4.6 \mathrm{~N} / \mathrm{mm}^{2}$ (for plain cement mortar) to $4.87 \mathrm{~N} / \mathrm{mm}^{2}, 5.41 \mathrm{~N} / \mathrm{mm}^{2}, 5.64 \mathrm{~N} / \mathrm{mm}^{2}, 6.05$ $\mathrm{N} / \mathrm{mm}^{2}$ and $7.01 \mathrm{~N} / \mathrm{mm}^{2}$ when the bar chip fibers were added in $0.5 \%, 1.0 \%, 1.5 \%, 2.0 \%$ and $2.5 \%$ (respectively) of volume of specimens. The flexural strength of mortar prism at 28 days had shown an increase from $5.8 \mathrm{~N} / \mathrm{mm}^{2}$ (for plain cement mortar) to $6.08 \mathrm{~N} / \mathrm{mm}^{2}, 6.83 \mathrm{~N} / \mathrm{mm}^{2}$, $7.88 \mathrm{~N} / \mathrm{mm}^{2}, 8.26 \mathrm{~N} / \mathrm{mm}^{2}$ and $8.60 \mathrm{~N} / \mathrm{mm}^{2}$ when barchip fibers were added to cement mortar in proportion of $0.5 \%$, $1 \%, 1.5 \%, 2 \%$ and $2.5 \%$ (respectively) of volume of specimens. The results indicate that the barchip fibers have influenced the strength of ferrocement mortar in terms of cube compressive strength, split-tensile and mortar flexural strength at 28 days.

\subsection{Impact Test Results}

Based on the number of blows received by FRF slabs (test specimens which has used reinforcement combination of III/ IV / V layer 'P' mesh and "PL" fibers of $0.5 \%, 1 \%$, $1.5 \%, 2 \%$ and $2.5 \%$ ), the energy absorbed by the slabs during impact has been calculated and shown in Table 10.

The impact energy results of FRF slabs of this research work have been compared with the studies of Sakthivel et al. (2012 b) [27] on ferrocement slabs reinforced with III, IV and V layer 'P' mesh (without fibers). On comparing the FRF and ferrocement slabs, it is seen from Table 10 that there is an increase in energy absorption at ultimate specimen failure from $423.792 \mathrm{~J}$ (for ferrocement slabs reinforced with III layer ' $\mathrm{P}$ ' mesh) to $470.880 \mathrm{~J}$, $570.942 \mathrm{~J}, 765.180 \mathrm{~J}, 1100.682 \mathrm{~J}$ and $1306.692 \mathrm{~J}$, when "PL" fibers were added in the proportion of $0.5 \%, 1 \%, 1.5 \%$, 
$2 \%$ and $2.5 \%$ at the time of casting ferrocement slabs with III layer ' $\mathrm{P}$ ' mesh. From the energy absorption values, we can infer that when PL fibers are added in proportion of $0.5 \%, 1 \%, 1.5 \%, 2 \%$ and $2.5 \%$ (of volume of specimens) as reinforcement combination to ferrocement slabs with III layer ' $\mathrm{P}$ ' mesh, an increase in impact strength is observed in FRF slabs to the extent of 1.11, 1.35, 1.81, 2.6 and 3.08 times (respectively) of that of ferrocement slabs cast with 'P' mesh III layers only.

And for the ferrocement slabs with IV layer ' $\mathrm{P}$ ' mesh, the energy absorption at ultimate failure was $523.854 \mathrm{~J}$. For FRF slabs, it has increased from $523.854 \mathrm{~J}$ to $576.828 \mathrm{~J}$, 941.760 J, $1165.428 \mathrm{~J}, 1283.148 \mathrm{~J}$ and $1536.246 \mathrm{~J}$ when "PL" fibers were added at $0.5 \%, 1 \%, 1.5 \%, 2 \%$ and $2.5 \%$ of volume of specimens, during casting of slabs with IV layer 'P' mesh. We can interpret from this that when "PL" fibers of $0.5 \%, 1 \%, 1.5 \%, 2 \%$ and $2.5 \%$ were added to ferrocement slabs in addition to IV layer ' $\mathrm{P}$ ' mesh, an increase in impact strength of FRF slabs of about 1.10, $1.80,2.22,2.45$ and 2.93 times (respectively) of that of ferrocement slabs cast with IV layer 'P' mesh is achieved.

Table 10 Impact Blows and Energy Absorbed by Ferrocement Slabs (with and without Barchip fibers)

\begin{tabular}{|c|c|c|c|}
\hline $\begin{array}{r}\text { No. of PVC (P) } \\
\text { coated Mesh Layers } \\
\text { \& Percentage of } \\
\text { Polyolefin (PL) } \\
\text { Fibers }\end{array}$ & $\begin{array}{r}\text { Energy } \\
\text { absorbed at } \\
\text { Initial Crack } \\
\\
\text { in Joules } \\
\text { (No. of Initial } \\
\text { Blows are } \\
\text { shown in } \\
\text { Brackets) } \\
\text { (A) }\end{array}$ & $\begin{array}{r}\text { Energy } \\
\text { absorbed at } \\
\text { Ultimate } \\
\text { Failure } \\
\text { in Joules } \\
\text { (No. of Final } \\
\text { Blows are } \\
\text { shown in } \\
\text { Brackets) } \\
\text { (B) }\end{array}$ & $\begin{array}{r}\text { IRS } \\
\text { Ratio }\end{array}$ \\
\hline P-III L & $35.316(6)$ & $423.792(72)$ & 12.00 \\
\hline P-III L + PL-0.5\% & $35.316(6)$ & $470.880(80)$ & 13.33 \\
\hline P-III L + PL-1.0\% & $41.202(7)$ & $570.942(97)$ & 13.86 \\
\hline P-III L + PL-1.5\% & $52.974(9)$ & $765.180(130)$ & 14.44 \\
\hline P-III L + PL-2.0\% & $70.632(12)$ & $1100.682(187)$ & 15.58 \\
\hline P-III L + PL-2.5\% & $82.404(14)$ & $1306.692(222)$ & 15.86 \\
\hline P-IV L & $41.202(7)$ & 523.854 (89) & 12.71 \\
\hline P-IV L + PL-0.5\% & $41.202(7)$ & 576.828 (98) & 14.00 \\
\hline P-IV L + PL-1.0\% & $64.746(11)$ & $941.760(160)$ & 14.54 \\
\hline P-IV L + PL-1.5\% & $76.518(13)$ & $1165.428(198)$ & 15.23 \\
\hline P-IV L + PL-2.0\% & $82.404(14)$ & $1283.148(218)$ & 15.57 \\
\hline P-IV L + PL-2.5\% & $94.176(16)$ & $1536.246(261)$ & 16.31 \\
\hline $\mathrm{P}-\mathrm{V}$ L & $88.290(15)$ & 1135.998 (193) & 12.87 \\
\hline P-V L + PL-0.5\% & $88.290(15)$ & $1247.832(212)$ & 14.13 \\
\hline P-V L + PL-1.0\% & $94.176(16)$ & $1406.754(239)$ & 14.94 \\
\hline P-V L + PL-1.5\% & $100.062(17)$ & $1542.132(262)$ & 15.41 \\
\hline P-V L + PL-2.0\% & $105.948(18)$ & 1701.054 (289) & 16.05 \\
\hline P-V L + PL-2.5\% & $105.948(18)$ & 1818.774 (309) & 17.17 \\
\hline
\end{tabular}

Similarly, slabs with V layer PVC mesh had energy absorption at ultimate failure of 1135.998 J. FRF slabs with $\mathrm{V}$ layer 'P' mesh and PL fibers of $0.5 \%, 1 \%, 1.5 \%$, $2 \%$ and $2.5 \%$ has given an energy absorption of $1247.832 \mathrm{~J}$, 1406.754 J, $1542.132 \mathrm{~J}, 1701.054 \mathrm{~J}$ and $1818.774 \mathrm{~J}$ respectively. This means that the combination of "PL" fibers (of $0.5 \%, 1 \%, 1.5 \%, 2 \%$ and $2.5 \%$ ) and V layer ' $\mathrm{P}$ ' mesh has given an increase in impact strength of about 1.1,
1.24, 1.36, 1.5 and 1.6 times (respectively) to that of slabs reinforced with ferrocement slabs with V layer 'P' mesh.

\subsection{Residual Impact Strength}

The Residual Impact Strength (IRS) Ratio have been computed based on energy absorbed at initial crack and ultimate failure of the specimen and shown in Table 10.

The IRS ratios for ferrocement slabs with III, IV and V layer ' $\mathrm{P}$ ' meshes are 12, 12.71 and 12.87 respectively (Sakthivel et al. 2012b) [27]. The IRS values for FRF slabs show values ranging from 13.33 to $15.86,14.00$ to 16.31 , and 14.13 to 17.17 corresponding to P-III + PL 0.5\%-2.5\%, $\mathrm{P}-\mathrm{IV}+\mathrm{PL} 0.5 \%-2.5 \%$ and $\mathrm{P}-\mathrm{V}+\mathrm{PL} 0.5 \%-2.5 \%$ (respectively). An increasing trend of IRS is observed when number of PVC-coated mesh layers as well as the percentage of barchip fibers are increased.

\subsection{Cracking Studies}

The initial and final crack-width have been measured using the Brinell's crack-measuring microscope, and presented in Table 11. The crack-patterns on slabs received during impact are demonstrated for III, IV and V layer ' $\mathrm{P}$ ' mesh (with and without barchip fibers) in Figs. 4a-4f, 5a-5f and 6a-6f. respectively.

Table 11 Crack Width of Cementitious Slabs subjected to Impact Loads

\begin{tabular}{|c|c|c|}
\hline $\begin{array}{l}\% \text { of Bar-chip } \\
\text { Fibers Used }\end{array}$ & $\begin{array}{r}\text { Initial } \\
\text { Crack Width } \\
\text { (in mm) }\end{array}$ & $\begin{array}{r}\text { Crack } \\
\text { Width (at } \\
\text { ultimate } \\
\text { specimen } \\
\text { failure) } \\
\text { (in mm) }\end{array}$ \\
\hline P-III L & 0.12 & 0.47 \\
\hline P-III L + PL-0.5\% & 0.20 & 0.38 \\
\hline P-III L + PL-1.0\% & 0.14 & 0.25 \\
\hline P-III L + PL-1.5\% & 0.10 & 0.23 \\
\hline P-III L + PL-2.0\% & 0.08 & 0.19 \\
\hline P-III L + PL-2.5\% & 0.04 & 0.08 \\
\hline P-IV L & 0.11 & 0.22 \\
\hline P-IV L + PL-0.5\% & 0.10 & 0.13 \\
\hline P-IV L + PL-1.0\% & 0.09 & 0.10 \\
\hline P-IV L + PL-1.5\% & 0.07 & 0.09 \\
\hline P-IV L + PL-2.0\% & 0.05 & 0.08 \\
\hline P-IV L + PL-2.5\% & 0.03 & 0.05 \\
\hline $\mathrm{P}-\mathrm{V} \mathrm{L}$ & 0.08 & 0.13 \\
\hline P-V L + PL-0.5\% & 0.10 & 0.07 \\
\hline P-V L + PL-1.0\% & 0.09 & 0.06 \\
\hline P-V L + PL-1.5\% & 0.03 & 0.05 \\
\hline P-V L + PL-2.0\% & 0.02 & 0.04 \\
\hline P-V L + PL-2.5\% & 0.01 & 0.02 \\
\hline
\end{tabular}

From Table 11, it is seen that the initial crack width is 0.12 $\mathrm{mm}, 0.11 \mathrm{~mm}$ and $0.08 \mathrm{~mm}$ and final crack width of 0.47 $\mathrm{mm}, 0.22 \mathrm{~mm}$ and $0.13 \mathrm{~mm}$ for ferrocement slabs using ' $\mathrm{P}$ ' mesh of III, IV and V layers respectively. A reduction in crack-width has been observed when the number of mesh layers were increased in ferrocement slabs from III to V layers (Sakthivel et al. 2012 b) [27]. 

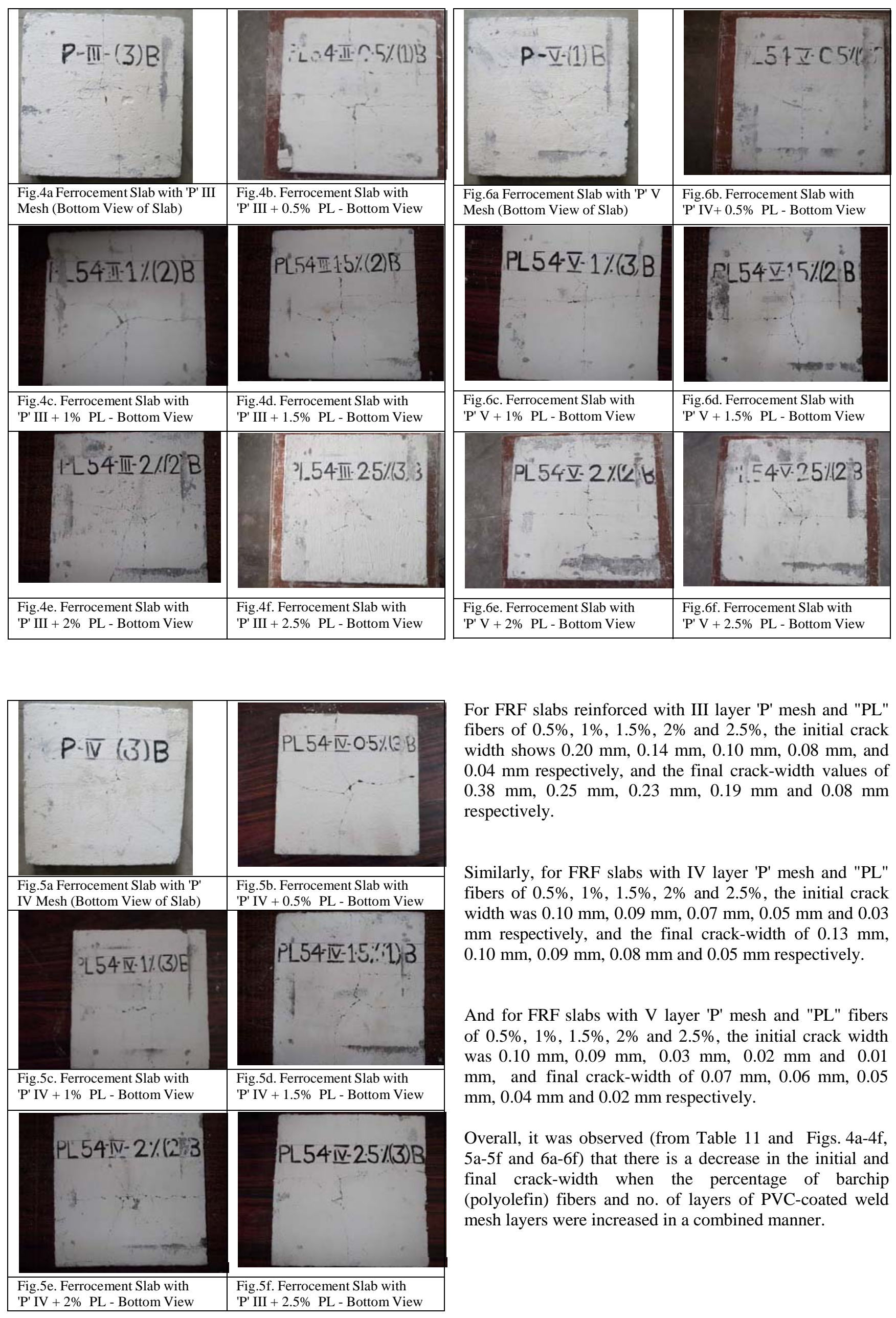

For FRF slabs reinforced with III layer 'P' mesh and "PL" fibers of $0.5 \%, 1 \%, 1.5 \%, 2 \%$ and $2.5 \%$, the initial crack width shows $0.20 \mathrm{~mm}, 0.14 \mathrm{~mm}, 0.10 \mathrm{~mm}, 0.08 \mathrm{~mm}$, and $0.04 \mathrm{~mm}$ respectively, and the final crack-width values of $0.38 \mathrm{~mm}, 0.25 \mathrm{~mm}, 0.23 \mathrm{~mm}, 0.19 \mathrm{~mm}$ and $0.08 \mathrm{~mm}$ respectively.

Similarly, for FRF slabs with IV layer 'P' mesh and "PL" fibers of $0.5 \%, 1 \%, 1.5 \%, 2 \%$ and $2.5 \%$, the initial crack width was $0.10 \mathrm{~mm}, 0.09 \mathrm{~mm}, 0.07 \mathrm{~mm}, 0.05 \mathrm{~mm}$ and 0.03 $\mathrm{mm}$ respectively, and the final crack-width of $0.13 \mathrm{~mm}$, $0.10 \mathrm{~mm}, 0.09 \mathrm{~mm}, 0.08 \mathrm{~mm}$ and $0.05 \mathrm{~mm}$ respectively.

And for FRF slabs with $\mathrm{V}$ layer ' $\mathrm{P}$ ' mesh and "PL" fibers of $0.5 \%, 1 \%, 1.5 \%, 2 \%$ and $2.5 \%$, the initial crack width was $0.10 \mathrm{~mm}, 0.09 \mathrm{~mm}, 0.03 \mathrm{~mm}, 0.02 \mathrm{~mm}$ and 0.01 $\mathrm{mm}$, and final crack-width of $0.07 \mathrm{~mm}, 0.06 \mathrm{~mm}, 0.05$ $\mathrm{mm}, 0.04 \mathrm{~mm}$ and $0.02 \mathrm{~mm}$ respectively.

Overall, it was observed (from Table 11 and Figs. 4a-4f, $5 a-5 f$ and 6a-6f) that there is a decrease in the initial and final crack-width when the percentage of barchip (polyolefin) fibers and no. of layers of PVC-coated weld mesh layers were increased in a combined manner. 


\section{CONCLUSION}

\section{This study concludes the following:}

1. Addition of barchip polyolefin fibers in cementitious matrix has shown substantial increase in the compressive, split tensile and mortar flexural strength, when compared to plain cement mortar. Both PVC-coated weld mesh and synthetic barchip polyolefin fibers can be effectively used as non-corrosive reinforcing materials in ferrocement.

2. The energy absorption of fiber-reinforced ferrocement slabs (reinforced with PVC-coated weld mesh and barchip fibers) is higher than that of ferrocement slabs (cast with PVC-coated weld mesh only). Also, the energy absorption of fiber-reinforced ferrocement slab elements increases when the number of PVC-coated mesh layers is increased (from III to V layers) while maintaining the percentage of polyolefin fibers constant, and also when the number of PVC-coated mesh layers is kept constant while increasing the percentage of polyolefin fibers (from $0.5 \%$ to $2.5 \%$ ).

3. Also, increasing the barchip fiber percentage in cementitious matrix (reinforced with PVC-coated weld mesh) has resulted in decrease of initial and final crack width.

4. This study recommends that fibrous ferrocement composites can be used in several construction works such as roads and pavements, industrial floors, roof slabs, water tanks, and in repair and rehabilitation works.

\section{ACKNOWLEDGEMENT}

The authors, Dr. P.B. Sakthivel and Dr. A. Jagannathan thank the Managements of Jerusalem College of Engineering, Chennai, India and Pondicherry Engineering College, Puducherry, India for the encouragement and support in conduct of experiments in the area of Fibrous Ferrocement Composites. The authors are grateful to Mr. Friedrich Aguasa, Managing Director, Elasto Plastic (Asia) Ltd. for organizing the Bar Chip $54 \mathrm{~mm}$ fiber material for this research work, and also to Mr. Girish Salian and Mr. Brajesh Malviya of Elkem South Asia Pvt. Ltd. for the timely supply of fiber material.

\section{REFERENCES}

[1] Nianzhi W, Mindess, S and Ko, K, "Fiber Reinforced Concrete Beams under Impact Loading", Cement and Concrete Composites, Vol.26 No.3, 1996, pp.363-376.

[2] Gencoglu M, and Mobasher B, "Static and Impact Behaviour of Fabric Reinforced Cement Composites in Flexure," in RILEM Proc. on High Performance Fiber Reinforced Cement Composites (HPFRCC 5), Pro. 53, S.A.R.L., Cachan, France, 2007, pp.463-470.

[3] Kuder KG, and Shah, SP, "Processing of High-Performance Fiber-reinforced Cement-based composites", Proc. 10th Int. Conf. on Inorganic-Bonded Fiber Composites, Brazil, 2006, pp.194-204.
[4] Oladele IO, Akinwekomi AD, Aribo S, and Aladenika, AK, "Development of Fiber Reinforced Cementitious Composite for Ceiling Application", J. of Minerals \& Materials Characterization \& Engineering, Vol.8 No. 8, 2009, pp.583-590.

[5] Balaguru, PN, and Shah, SP, Fiber-Reinforced Cement Composites. New York: Oxford University Press, 1992.

[6] Sakthivel PB, Jagannathan A, and Nagamani K, "Ferrocement Technology \& Quality Improvisation Techniques - A Review", Proc. 2nd Int. Conf. on Current trends in Technology (NUiCONE 2011) held at Institute of Technology, Nirma University, Ahmedabad, India, 08-10 December, 2011.

[7] Sakthivel PB, and Jagannathan A, "Fiber Reinforced Ferrocement - A Review Study", Proc. 2nd Int. Conf. on Advances in Mechanical, Manufacturing and Building Sciences (ICAMB-2012), SMBS, VIT University, Vellore, India, 09 January 2012 (a), pp.1172-1177.

[8] Rahim A, and Srinivasa Rao P, "Effect of incorporating metakaolin as mineral admixture and crimped fibers on properties of high strength concrete", Proc. 7th Int. RILEM Symposium on Fiber Reinforced Concrete: Design and Applications (BEFIB 2008), 2008, pp.155-159.

[9] Patil NK, and Prakash KB, "An experimental investigation on effect of alternate wetting and drying on impact strength of fibrous ferrocement using rounded steel fibers", www.nbmcw.com/articles/miscellaneous/others/2004impact-strength-of-fibro...2009.

[10] Alwan, JM, Naaman, AE, and Hansen W, "Pull-out Work on Steel Fibers from Cementitious Composites: Analytical Investigation", Cement \& Concrete Composites, Vol.13, 1991, pp.247-255.

[11] Currie B, and Gardiner T, "Bond between polypropylene fibers and cement matrix", Int. J. Cement Composites and Lightweight Concrete", Vol.11, 1989, pp.3-9

[12] Leung CK, and Li VC, "A new strength-based model for the debonding of discontinuous fibers in an elastic matrix", Report UMCE 90-17, Dept. of Civil Engineering, University of Michigan, Ann Arbor, 1990.

[13] Mandel J, Wei S, and Said S, "Studies of the properties of the fiber-matrix interface in steel fiber reinforced mortar", ACI Materials J., Vol.84, 1987, pp.101-9.

[14] Stang H, and Shah SP, "Failure of fiber-reinforced composites by pull-out fracture", J. Mat. Sci., Vol.21, 1986, pp.953-7.

[15] Wei S, Mandel J, and Said S, "Study of the interface strength in steel fiber-reinforced cement based composites", ACI Materials J., Vol.83, 1986, pp.597-605.

[16] Banthia N, and Nandakumar N, "Crack Growth resistance of hybrid fiber reinforced cement composites", Cement \& Concrete Composites, Vol.25, 2003, pp.3-9.

[17] Kumar S, and Prasad MM, "Flexural Behaviour of short steel fiber reinforced concrete beams", Proc. 7th Int. RILEM Symposium on Fiber Reinforced 
Concrete: Design and Applications (BEFIB 2008), 2008, pp.209-217.

[18] Sadhasiva Murthy TH, and Ambalavannan R, "Static and Fatigue Behaviour of RC Beams incorporating steel fibers in addition to flyash and silica fume as binary and tertiary blends", Proc. of ICFRC Int. Conf. on Fiber Composites, High Performance Concrete and Smart Materials, 8-10 January, 2004, Chennai, India, pp.223-224.

[19] Kulkarni MV, Elangovan K, Hemachandra Reddy K, and Prakash JN, "Enhancement of Impact resistance property of Nylon6 by the addition of $\mathrm{CaSiO}_{3}$ as a filler material," Int. J. of Applied Engineering Research, Dindigul, Vol.2 No.2, 2011, pp.343-349.

[20]Naaman AE, "Ferrocement and Laminated Cementitious Composites", Techno Press 3000, Michigan, USA, 2000.

[21] ACI 549, "State of the Art Report on Ferrocement", ACI 549-R97, in Manual of Concrete Practice, American Concrete Institute, Farmington Hills, Michigan, USA, 1997.

[22] Sakthivel PB, and Jagannathan A, "Ferrocement Construction Technology and its Applications - A Review", Proc. Int. Conf. on Structural Engineering, Construction and Management (ICSECM-2011), Kandy, Sri Lanka, 15-17 December, 2011.

[23] Sakthivel PB, and Jagannathan A, "Study of Flexural Ferrocement and Thin Reinforced Cement Behaviour of Ferrocement Slabs Reinforced with PVC-coated Weld Mesh", International Journal of Engineering Research and Development, Vol.1 No.12, 2012 (b), pp.50-57.

[24] Sakthivel PB, and Jagannathan A, "Corrosion-free Cementitious Composites for Sustainability," Proc. 37th Conference on Our World in Concrete \& Structures", Singapore, Vol. XXXI, 29-31 Aug. 2012 (c), pp.361-371.

[25] Sakthivel, PB and Jagannathan A, "Compatibility Study of PVC-coated Weld Mesh in Thin Reinforced Cementitious Matrix," Proc. 10th Int. Symposium on
Composites (FERRO-10), Havana, Cuba, October 2012 (d), pp.17-27.

[26] Sakthivel, PB, Jagannathan A, and Padmanaban R, "Thin Cementitious Slabs reinforced with Stainless Steel Fibers", IOSR Journal of Mechanical and Civil Engineering, Vol.4 No.2, 2012 (a), pp.39-45.

[27] Sakthivel, PB, Jagannathan A, and Padmanaban R, "Influence of Fibers on Impact of Ferrocement Slabs Reinforced with PVC-Coated Weld Mesh", Proc. 28th National Convention of Civil Engineers \& National Seminar on Role of Infrastructure for Sustainable Development, The Institution of Engineers (India), Roorkee Local Centre, IIT Roorkee Campus, 2012 (b), pp.281-290.

[28] IS 12269: 1989, Specification for 53 Grade Ordinary Portland Cement, Bureau of Indian Standards, New Delhi, India.

[29] IS 383: 1970 - Specifications for Coarse and Fine Aggregates from Natural Sources for concrete, Bureau of Indian Standards, New Delhi, India.

[30] IS 2386 (Part-VII: 1963) Reaffirmed 2002; Methods of Test for Aggregates for Concrete Part VII Alkali Aggregate Reactivity (Incorporating Amendment No.1), Bureau of Indian Standards, New Delhi, India.

[31] Hodhod H, and Abdeen MAM, "Experimental Investigation and Numerical Modelling of the Effect of Natural and Steel Fibers on the Performance of Concrete", International Journal of Engineering, Vol.4 No.5, 2010, pp.321-337.

International Journal of GEOMATE , Dec., 2012, Vol. 3, No. 2 (Sl. No. 6), pp.381-388.

MS No. 2015 received Oct. 2, 2012, and reviewed under GEOMATE publication policies.

Copyright (C) 2012, International Journal of GEOMATE. All rights reserved, including the making of copies unless permission is obtained from the copyright proprietors. Pertinent discussion including authors' closure, if any, will be published in the Dec. 2013 if the discussion is received by June, 2013.

Corresponding Author: P.B. Sakthivel 